\title{
SYNTHESIS AND ANTITUBERCULAR ACTIVITY OF SOME MANNICH BASES DERIVED FROM ISATIN ISONICOTINIC ACID HYDRAZONE
}

\author{
Mostafa A. Hussein ${ }^{1 *}$, Tarek Aboul-Fadl ${ }^{2}$, and Asmma Hussein ${ }^{3}$
}

${ }^{1}$ Department of Pharmaceutical Organic Chemistry, ${ }^{2}$ Department of Pharmaceutical Medicinal Chemistry, Faculty of Pharmacy and ${ }^{3}$ Department of Animal hygiene and Zoonoses, Faculty of Veterinary Medicine, Assiut University, Assiut-71526, Egypt

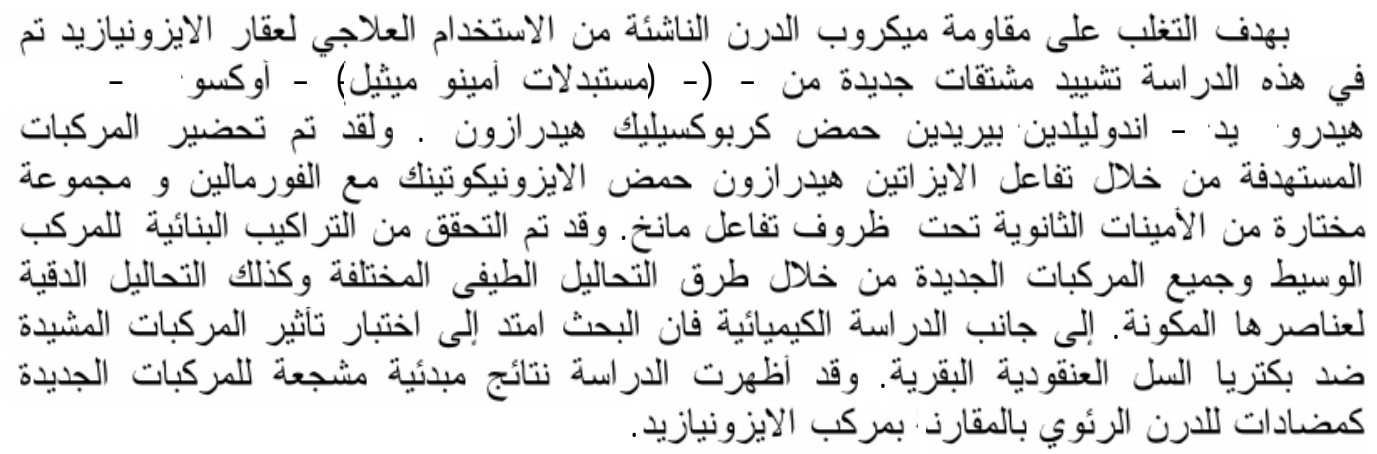

The purpose of this study based on the design and synthesis of a new series of 4-[1(substitutedaminomethyl)]-2-oxo-2,3-dihydro-1H-3-indolylidene-pyridine- carboxylic acid hydrazones (2a-g) in a trial to overcome the resistance developed with the therapeutic uses of isonicotinic acid hydrazide (isoniazid, INH). The new compounds were prepared by reacting isatin isonicotinic acid hydrazone with formalin and the appropriate secondary amines. The structures of the newly synthesized compounds were elucidated using different spectral data (IR, ${ }^{1} H N M R$, and ${ }^{13}$ CNMR) as well as elemental methods of analyses. The lipophilicity of the synthesized compounds supercedes that of INH as expressed by Clog $P$.

The new compounds (2a-g) as well as INH as a reference drug were tested for their antitubercular activity against bovine Mycobacterium tuberculosis at a dose level of $10 \mu \mathrm{mol}$. The tested compounds exhibited comparable inhibitory activity against the tested TB strain comparing to INH a reference drug.

\section{INTRODUCTION}

Tuberculosis is a worldwide public health problem and its causal organism is mainly Mycobacterium tuberculosis and rarely Mycobacterium bovis or Mycobacterium africanum. Approximately, one third of the earth's population is infected with Mycobacterium tuberculosis bacteria, ten percent became risk. ${ }^{1,2}$ Despite the intensive treatment with drugs such as $p$-aminosalicylic acid, rifampicin, isoniazide (INH), ethinamide, streptomycin, pyrazinamide, and ethambutol, disease control has not been successful due to mistreatment and insufficient knowledge. ${ }^{1-3}$
First choice mono or multidrug medication faces limitations because of the drug resistance shown by Mycobacterium tuberculosis. ${ }^{3-8}$ This alarming sign of spreading of endemic disease and the fact that drug resistant cultures have emerged on a massive scale underscore the importance of the search for new drugs to overcome such problems. Fortunately, pharmacokinetic properties and cellular permeability of a drug can be modulated by derivatization to more lipophilic forms. ${ }^{9}$ On the other hand, isatin (2,3-dioxoindole) derivatives were reported to possess a variety of biological activities such as antibacterial, ${ }^{10}$ antifungal, ${ }^{11}$ 
antiviral, ${ }^{12}$ anti-HIV, ${ }^{13}$ and antitubercular activities. ${ }^{5,14}$

It was interested that the design a new drug molecule not only inhaling the pharmacophores of both INH and isatin but also more lipophilic which may be in an advantageous position and could be expected to exhibit an enhanced antitubercular activity. The current study describes the preparation of some new Mannich bases through the reaction of isatin isonicotinic acid hydrazone $e^{5,15}$ with formalin and the appropriate secondary amines. It is interesting to investigate the antitubercular activity of the synthesized compounds against bovine Mycobacterium tuberculosis in comparison to INH as a reference drug.

\section{EXPERIMENTAL}

\section{Materials and equipments:}

Melting points were determined on an electrothermal melting point apparatus [Stuart Scientific, UK], and were uncorrected. Precoated silica gel plates (kiesel gel $0.25 \mathrm{~mm}$, 60G F254, Merck) were used for thin layer chromatography. Developing solvent system of chloroform/methanol (7:3) was used and the spots were detected by ultraviolet light and/or iodine.

IR spectra ( $\mathrm{KBr}$ disc) were recorded on IR-470 Shimadzu spectrophotometer, Japan. ${ }^{1}$ HNMR Spectra were scanned on a Varian EM-360 L NMR spectrophotometer (60 MHZ) USA. Chemical shifts are expressed in $\delta$-values (ppm) relative to TMS as an internal standard, using $\mathrm{CDCl}_{3}$ as a solvent. ${ }^{13} \mathrm{CNMR}$ Spectra were scanned on a Varian EM-360 L NMR spectrophotometer (25.2 MHz), University of Utah, USA using $\mathrm{CDCl}_{3}$ as a reference. Elemental analyses were performed at the Department of Chemistry, Faculty of Science, Assiut University, Assiut, Egypt. The log P values of the synthesized derivatives as well as INH, were computed with a routine method called calculated $\log \mathrm{P}(\mathrm{Clog} \mathrm{P})$ contained in a PC-software package. The antitubercular activity was performed at the Department of Animal Hygiene and Zoonoses, Faculty of Veterinary medicine, Assiut University, and the Chest Hospital, Assiut Governorate, Assiut, Egypt.

\section{Chemistry}

Synthesis of 3-[(Pyridin-4-yloxymethyl)hydrazono]-1,3-dihydro-indol-2-one, compound (1)

Equimolar amounts of isatin $(14.7 \mathrm{~g}, 0.1$ mole) and isoniazide (13.7 g, 0.1 mole) were dissolved in ethanol $(100 \mathrm{~mL})$, and glacial acetic acid $(1.0 \mathrm{~mL})$ was added. The reaction mixture was refluxed for 4 hours and left at room temperature. The resulting solid was separated by filtration, washed with aqueous ethanol, dried and crystallized from ethanol/chloroform as a yellow crystalline solid, $25.2 \mathrm{~g}$ (yield $95 \%$ and $\mathrm{mp} 292-5^{\circ}$, as reported). ${ }^{5,15}$

Synthesis of 4-[1-(substitutedaminomethyl)]2-oxo-2,3-dihydro-1H-3-indolylidenepyridinecarboxylic acid hydrazones (2a-g)

The appropriate secondary amine $(0.014$ mole) was added dropwise with continuous stirring to a cold mixture of compound 1 (2.66 g, 0.01 mole) and formaldehyde $(1.14 \mathrm{~mL}$, 0.014 mole $)$ in ethanol $(20 \mathrm{~mL})$. The reaction mixture was stirred at the ambient temperature for 1 hour and left overnight. The solid separated was collected by filtration, washed with aqueous ethanol, dried and crystallized from ethanol. Yields, melting points $\mathrm{R}_{\mathrm{f}}$ and Clog $\mathrm{P}$ data are given in Table $\mathbf{1}$.

\section{Calculation of $\log P$ values}

The $\log \mathrm{P}$ values of the synthesized derivatives as well as INH, were computed with a routine method called calculated $\log \mathrm{P}$ (Clog P) contained in a PC-software package (MacLogP 2.0, BioByte Corp., CA, USA). A representation of the molecular structure where hydrogens are omitted, or 'suppressed' (SMILES notation), is entered into the program, which computes the $\log \mathrm{P}$ based on 
the fragment method developed by Leo, ${ }^{16}$ the results are given in Table $\mathbf{1}$.

\section{Antitubercular activity}

The antitubercular activity of the tested compounds, were carried out using Rist and Grosset proportion method. ${ }^{17}$ The synthesized compounds (2a-g) and the INH, were solubilized in dimethyl sulfoxide at a concentration of $100 \mu \mathrm{mol}$. The appropriate amounts of the tested compound were diluted with Lowenstein-jensen media to give concentrations of $10 \mu \mathrm{mol}$ of the growth media. The media containing different compounds were inspissated at $70^{\circ}$ for one hour in hot air oven for three successive days. The sterilized media were then inoculated by $10-3$ and $10-5$ dilutions of the reference strain [Bovin T.B., reference strain]. The growth and inhibitory activity of the tested compounds were evaluated after incubation at $37^{\circ}$ for six weeks. Each batch of tests included a control experiment using the standard strain of Bovin T.B., in a media free from drugs. The molar concentrations of compounds (2a-g) and INH for antitubercular activity are given in Table 4 and a representitive of the results is in Figure 1.

\section{RESULTS AND DISCUSSION}

\section{Chemistry}

The new compounds (2a-g) were synthesized by treating compound $\mathbf{1}^{5,15}$ with formalin and different secondary amines in ethanol at room temperature, Scheme 1.

The chemical structures of these Mannich compounds (2a-g) were verified by spectral (IR, ${ }^{1} \mathrm{HNMR}$, and ${ }^{13} \mathrm{CNMR}$ ) as well as elemental analyses, Tables 1, 2 and 3 .

All the spectral data of the new compounds (2a-g) are in accordance with the proposed structures. The IR spectra of compounds 2a-g showed prominent strong absorption bands around $3400-3350 \mathrm{~cm}^{-1}(\mathrm{NH}$ stretch), in addition to, an absorption bands at about the range $1710-1650 \mathrm{~cm}^{-1}$ (two $\mathrm{C}=\mathrm{O}$ stretch). ${ }^{1}$ HNMR spectra, with some exceptional cases, revealed a common pattern for the eight aromatic protons. The ${ }^{1} \mathrm{HNMR}$ patterns of the $\mathrm{N}-1$ substituents are in accordance with the expected structures of the designed compounds, Table 2 .

On the other hand, the carbon skeletons of the newly synthesized compounds were assigned from the decoupled ${ }^{13} \mathrm{CNMR}$ spectra. The aliphatic as well as the aromatic carbons gave signals that comply with the expected patterns. Moreover, the two carbonyl groups (quaternary carbons) appear with the lowest intensity in the range of 151-176 ppm, Table 3.<smiles>[Y6]CN1C(=O)C(=NOc2ccncc2)c2cccc(CN[R16])c21</smiles>

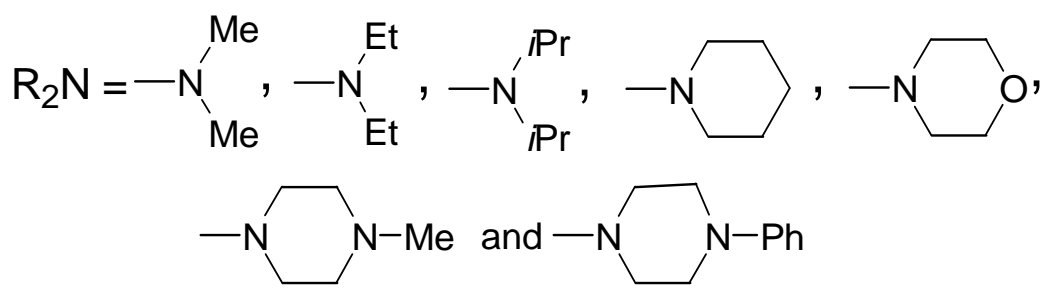

Scheme 1 
Table 1: 4-[1-(Substitutedaminomethyl)]-2-oxo-2,3-dihydro-1H-3-indolylidene- pyridinecarboxylic acid hydrazones (2a-g).<smiles>CN1C(=O)C(=N)c2ccccc21</smiles>

\begin{tabular}{|c|c|c|c|c|c|c|c|c|c|}
\hline \multirow{2}{*}{$\begin{array}{c}\text { Compd.N } \\
\text { o. }\end{array}$} & \multirow{2}{*}{$\mathrm{NR}_{2}$} & \multirow{2}{*}{$\begin{array}{l}\text { Mol. Formula } \\
\text { (M. Wt.) }\end{array}$} & \multirow{2}{*}{$\begin{array}{l}\text { Yield } \\
\%\end{array}$} & \multirow{2}{*}{$\mathrm{MP},{ }^{\circ}$} & \multirow{2}{*}{$\mathrm{R}_{\mathrm{f}}^{\mathrm{a}}$} & \multirow{2}{*}{$\mathrm{C} \log \mathrm{P}^{\mathrm{b}}$} & \multicolumn{3}{|c|}{ Microanalysis } \\
\hline & & & & & & & $\mathrm{C} \%$ & $\mathrm{H} \%$ & N\% \\
\hline $2 \mathbf{a}$ & $\mathrm{NMe}_{2}$ & $\begin{array}{c}\mathrm{C}_{17} \mathrm{H}_{17} \mathrm{~N}_{5} \mathrm{O}_{2} \\
(323.36)\end{array}$ & 55 & $234-6$ & 0.27 & 1.727 & $\begin{array}{l}63.15 \\
62.82 \\
\end{array}$ & $\begin{array}{l}5.30 \\
5.45\end{array}$ & $\begin{array}{l}21.66 \\
21.90 \\
\end{array}$ \\
\hline $2 \mathrm{~b}$ & $\mathrm{NEt}_{2}$ & $\begin{array}{c}\mathrm{C}_{19} \mathrm{H}_{21} \mathrm{~N}_{5} \mathrm{O}_{2} \\
(351.40) \\
\end{array}$ & 60 & $158-9$ & 0.35 & 2.705 & $\begin{array}{l}64.94 \\
64.45 \\
\end{array}$ & $\begin{array}{l}6.02 \\
6.34 \\
\end{array}$ & $\begin{array}{l}19.93 \\
19.72 \\
\end{array}$ \\
\hline $2 \mathrm{c}$ & $\mathrm{NiPr}_{2}$ & $\begin{array}{c}\mathrm{C}_{21} \mathrm{H}_{25} \mathrm{~N}_{5} \mathrm{O}_{2} \\
(379.47) \\
\end{array}$ & 80 & $177-8$ & 0.50 & 3.323 & $\begin{array}{l}66.47 \\
66.53 \\
\end{array}$ & $\begin{array}{l}6.64 \\
6.80 \\
\end{array}$ & $\begin{array}{l}18.46 \\
18.21 \\
\end{array}$ \\
\hline $2 d$ & Piperidenyl & $\begin{array}{c}\mathrm{C}_{20} \mathrm{H}_{21} \mathrm{~N}_{5} \mathrm{O}_{2} \\
(363.42)\end{array}$ & 70 & $204-5$ & 0.43 & 3.160 & $\begin{array}{l}66.10 \\
66.15\end{array}$ & $\begin{array}{l}5.82 \\
6.01\end{array}$ & $\begin{array}{l}19.27 \\
18.77\end{array}$ \\
\hline $2 e$ & Morphilino & $\begin{array}{c}\mathrm{C}_{19} \mathrm{H}_{19} \mathrm{~N}_{5} \mathrm{O}_{3} \\
(365.40)\end{array}$ & 90 & $224-5$ & 0.35 & 1.891 & $\begin{array}{l}62.46 \\
61.80\end{array}$ & $\begin{array}{l}5.24 \\
5.91\end{array}$ & $\begin{array}{l}19.17 \\
19.15 \\
\end{array}$ \\
\hline $2 f$ & $\begin{array}{l}\text { N-Methyl- } \\
\text { piperazinyl }\end{array}$ & $\begin{array}{c}\mathrm{C}_{20} \mathrm{H}_{22} \mathrm{~N}_{6} \mathrm{O}_{2} \\
(378.44) \\
\end{array}$ & 76 & $168-9$ & 0.56 & 2.515 & $\begin{array}{l}63.48 \\
63.95 \\
\end{array}$ & $\begin{array}{l}5.86 \\
6.01 \\
\end{array}$ & $\begin{array}{l}22.21 \\
21.95 \\
\end{array}$ \\
\hline $2 \mathrm{~g}$ & $\begin{array}{l}\text { N-Phenyl- } \\
\text { piperazinyl }\end{array}$ & $\begin{array}{c}\mathrm{C}_{25} \mathrm{H}_{24} \mathrm{~N}_{6} \mathrm{O}_{2} \\
(440.51) \\
\end{array}$ & 72 & $163-5$ & 0.74 & 4.429 & $\begin{array}{l}68.17 \\
68.68 \\
\end{array}$ & $\begin{array}{l}5.49 \\
5.53 \\
\end{array}$ & $\begin{array}{l}19.08 \\
18.65 \\
\end{array}$ \\
\hline
\end{tabular}

${ }^{\mathrm{a}}$ Developing solvent system is chloroform/methanol (7:3). ${ }^{\mathrm{b}} \mathrm{Clog} \mathrm{P}$ value for INH is -0.708 (Reported $-0.700{ }^{16}$ )

Table 2: ${ }^{1} \mathrm{HNMR}$ data of compounds (2a-g) in $\mathrm{CDCl}_{3}$<smiles>CN1C(=O)/C(=N\N)c2ccccc21</smiles>

\begin{tabular}{|c|c|c|}
\hline $\begin{array}{c}\text { Compd. } \\
\text { No. }\end{array}$ & $\mathrm{R}$ & ${ }^{1}$ HNMR data \\
\hline $2 a$ & $\mathrm{NMe}_{2}$ & $\begin{array}{l}2.47\left(6 \mathrm{H}, \mathrm{s}, 2 \mathrm{CH}_{3}\right), 4.50\left(2 \mathrm{H}, \mathrm{s}, \mathrm{CH}_{2}\right), 7.07-7.67(4 \mathrm{H}, \mathrm{m}, \mathrm{Ar}-\mathrm{H}), 7.87-8.34(2 \mathrm{H}, \mathrm{m}, \mathrm{Ar}-\mathrm{H}) \text {, and } \\
8.74-9.14(3 \mathrm{H}, \mathrm{m}, \mathrm{Ar}-\mathrm{H} \text { and } \mathrm{NH}) \text {. }\end{array}$ \\
\hline $2 \mathbf{b}$ & $\mathrm{NEt}_{2}$ & $\begin{array}{l}1.34\left(6 \mathrm{H}, \mathrm{t}, 2 \mathrm{CH}_{3}\right), 3.10\left(4 \mathrm{H}, \mathrm{q}, 2 \mathrm{CH}_{2}\right), 5.44\left(2 \mathrm{H}, \mathrm{s}, \mathrm{CH}_{2}\right), 7.01-7.54(3 \mathrm{H}, \mathrm{m}, \mathrm{Ar}-\mathrm{H}), 8.10-8.34 \\
(2 \mathrm{H}, \mathrm{m}, \mathrm{Ar}-\mathrm{H}), 8.67-8.94(3 \mathrm{H}, \mathrm{m}, \mathrm{Ar}-\mathrm{H}) \text {, and } 10.20(1 \mathrm{H}, \mathrm{hump}, \mathrm{NH}) .\end{array}$ \\
\hline $2 c$ & $\mathrm{NiPr}_{2}$ & $\begin{array}{l}1.30\left(12 \mathrm{H}, \mathrm{d}, 4 \mathrm{CH}_{3}\right), 3.10-3.64(2 \mathrm{H}, \mathrm{m}, 2 \mathrm{CH}), 5.44\left(2 \mathrm{H}, \mathrm{s}, \mathrm{CH}_{2}\right), 7.14-7.57(3 \mathrm{H}, \mathrm{m}, \mathrm{Ar}-\mathrm{H}), \\
8.14-8.40(2 \mathrm{H}, \mathrm{m}, \mathrm{Ar}-\mathrm{H}), 8.57-8.97(3 \mathrm{H}, \mathrm{m}, \mathrm{Ar}-\mathrm{H}) \text {, and } 10.00(1 \mathrm{H}, \text { hump, NH). }\end{array}$ \\
\hline $2 d$ & Piperidenyl & $\begin{array}{l}1.20-1.72\left(6 \mathrm{H}, \mathrm{m}, 3 \mathrm{CH}_{2}\right), 2.40-2.85\left(4 \mathrm{H}, \mathrm{m}, 2 \mathrm{CH}_{2}\right), 4.64\left(2 \mathrm{H}, \mathrm{s}, \mathrm{CH}_{2}\right), 7.14-7.54(3 \mathrm{H}, \mathrm{m}, \mathrm{Ar}- \\
\mathrm{H}), 8.20-8.47(2 \mathrm{H}, \mathrm{m}, \mathrm{Ar}-\mathrm{H}), 8.80-9.07(3 \mathrm{H}, \mathrm{m}, \mathrm{Ar}-\mathrm{H}) \text {, and } 9.80(1 \mathrm{H}, \mathrm{hump}, \mathrm{NH}) .\end{array}$ \\
\hline $2 e$ & Morphilino & $\begin{array}{l}2.50-2.90\left(4 \mathrm{H}, \mathrm{t}, \mathrm{N}\left(\mathrm{CH}_{2}\right)_{2}, 3.60-3.97\left(4 \mathrm{H}, \mathrm{t}, \mathrm{O}\left(\mathrm{CH}_{2}\right)_{2}, 4.64\left(2 \mathrm{H}, \mathrm{s}, \mathrm{CH}_{2}\right), 7.08-8.17(7 \mathrm{H}, \mathrm{m},\right.\right. \\
\text { Ar-H and } \mathrm{NH}), 8.90-9.9(2 \mathrm{H}, \mathrm{m}, \mathrm{Ar}-\mathrm{H}) .\end{array}$ \\
\hline $2 f$ & $\begin{array}{l}\text { N-Methyl- } \\
\text { piperazinyl }\end{array}$ & $\begin{array}{l}2.34\left(3 \mathrm{H}, \mathrm{s}, \mathrm{CH}_{3}\right), 3.47-3.97\left(8 \mathrm{H}, \mathrm{m}, 4 \mathrm{CH}_{2}\right), 4.64\left(2 \mathrm{H}, \mathrm{s}, \mathrm{CH}_{2}\right), 7.10-7.44(4 \mathrm{H}, \mathrm{m}, \mathrm{Ar}-\mathrm{H}), \\
7.87-8.30(2 \mathrm{H}, \mathrm{m}, \mathrm{Ar}-\mathrm{H}), 8.90-9.17(2 \mathrm{H}, \mathrm{m}, \mathrm{Ar}-\mathrm{H}) \text {, and } 15.44(1 \mathrm{H}, \mathrm{hump}, \mathrm{NH}) .\end{array}$ \\
\hline $2 \mathrm{~g}$ & $\begin{array}{l}\text { N-Phenyl- } \\
\text { piperazinyl }\end{array}$ & $\begin{array}{l}2.57-3.00\left(4 \mathrm{H}, \mathrm{m},\left(\mathrm{CH}_{2}\right)_{2} \mathrm{NPh}\right), 3.07-3.47\left(4 \mathrm{H}, \mathrm{m},\left(\mathrm{CH}_{2}\right)_{2} \mathrm{~N}\right), 4.67\left(2 \mathrm{H}, \mathrm{s}, \mathrm{CH}_{2}\right), 6.80-7.74 \\
(9 \mathrm{H}, \mathrm{m}, \mathrm{Ar}-\mathrm{H}), 7.84-8.13(2 \mathrm{H}, \mathrm{m}, \mathrm{Ar}-\mathrm{H}), 8.15(1 \mathrm{H}, \mathrm{hump}, \mathrm{NH}) \text {, and 8.90-9.20 }(2 \mathrm{H}, \mathrm{m}, \mathrm{Ar}-\mathrm{H}) \text {. }\end{array}$ \\
\hline
\end{tabular}

$\mathrm{NH}$ exchangeable with $\mathrm{D}_{2} \mathrm{O}$. 
Table 3: ${ }^{13} \mathrm{CNMR}$ chemical shifts of compounds (2a-g)

\begin{tabular}{|c|c|c|}
\hline $\begin{array}{l}\text { Compd. } \\
\text { No. }\end{array}$ & $\mathrm{R}$ & ${ }^{13} \mathrm{CNMR}$ data \\
\hline $2 a$ & $\mathrm{NMe}_{2}$ & $\begin{array}{l}34.45\left(\mathrm{CH}_{3}\right), 42.98\left(\mathrm{CH}_{3}\right), 62.82\left(\mathrm{CH}_{2}\right), 109.61,117.56,122.84,123.36,126.47 \\
129.29,138.52,142.63,145.59,149.94(\mathrm{Ar}-\mathrm{C}), 169.61(\mathrm{C}=\mathrm{O}) \text {, and 176.17 }(\mathrm{C}=\mathrm{O}) \text {. }\end{array}$ \\
\hline $2 \mathrm{~b}$ & $\mathrm{NEt}_{2}$ & $\begin{array}{l}11.36\left(\mathrm{CH}_{3}\right), 41.95\left(\mathrm{CH}_{3}\right), 44.87\left(\mathrm{CH}_{2}\right), 58.87\left(\mathrm{CH}_{2}\right), 63.78\left(\mathrm{CH}_{2}\right), 109.01,110.19, \\
117.85,122.97,123.13,123.69,126.26,126.60,128.11,137.70,140.85,145.80, \\
149.82(\text { Ar-C), } 168.98(\mathrm{C}=\mathrm{O}) \text {, and } 176.10(\mathrm{C}=\mathrm{O}) .\end{array}$ \\
\hline $2 c$ & $\mathrm{NiPr}_{2}$ & $\begin{array}{l}\text { 19.30 }\left(\mathrm{CH}_{3}\right), 46.72(\mathrm{CH}), 63.96\left(\mathrm{CH}_{2}\right), 108.32,118.19,123.26,123.83,126.65, \\
129.06,137.52,140.99,146.25,149.94(\mathrm{Ar}-\mathrm{C}), 169.15(\mathrm{C}=\mathrm{O}) \text {, and } 175.96(\mathrm{C}=\mathrm{O}) .\end{array}$ \\
\hline $2 d$ & Piperidenyl & $\begin{array}{l}\text { 23.12, 24.27, 26.04, 44.21, and 52.27, (Piperidenyl), 62.83 }\left(\mathrm{CH}_{2}\right), 110.09,117.88, \\
123.12,123.30,126.55,129.21,138.76,143.82,146.09,150.13(\mathrm{Ar}-\mathrm{C}), 169.94 \\
(\mathrm{C}=\mathrm{O}) \text {, and } 176.16(\mathrm{C}=\mathrm{O}) \text {. }\end{array}$ \\
\hline $2 e$ & Morphilino & $\begin{array}{l}\text { 51.33, 62.41 (morphilino), } 65.84\left(\mathrm{CH}_{2}\right), 110.38,119.47,121.37,122.49,124.24, \\
132.31,138.56,139.35,143.78,151.13,151.26(\mathrm{Ar}-\mathrm{C}), 162.47(\mathrm{C}=\mathrm{O}) \text {, and } 162.92 \\
(\mathrm{C}=\mathrm{O}) \text {. }\end{array}$ \\
\hline $2 f$ & $\begin{array}{l}\text { N-Methyl- } \\
\text { piperazinyl }\end{array}$ & $\begin{array}{l}46.11\left(\mathrm{CH}_{3}\right), 50.92,54.87 \text { (piperazinyl), } 62.13\left(\mathrm{CH}_{2}\right), 107.60,111.05,119.46, \\
121.39,122.45,123.47,124.14,132.27,139.41,143.95,151.25(\mathrm{Ar}-\mathrm{C}), 162.47 \\
(\mathrm{C}=\mathrm{O}) \text {, and } 162.92(\mathrm{C}=\mathrm{O}) \text {. }\end{array}$ \\
\hline $2 g$ & $\begin{array}{l}\text { N-Phenyl- } \\
\text { piperazinyl }\end{array}$ & $\begin{array}{l}\text { 49.34, 51.09, 51.76 (piperazinyl), } 62.21\left(\mathrm{CH}_{2}\right), 111.01,116.28,116.58,117.12, \\
119.52,119.81,120.64,121.40,122.53,124.22,129.31,129.38,129.64,132.31, \\
143.83,(\text { Ar-C), } 151.29(\mathrm{C}=\mathrm{O}) \text {, and } 151.69(\mathrm{C}=\mathrm{O}) .\end{array}$ \\
\hline
\end{tabular}

\section{Lipophilicity}

Lipophilicity of the synthesized derivatives (2a-g) and $\mathrm{INH}$, is expressed in the term of $\mathrm{Clog} \mathrm{P}$ values. These values were computed with a routine method called calculated $\log \mathrm{P}(\mathrm{C} \log \mathrm{P})$ contained in a PCsoftware package as described in the experimental part. Computation of the $\log \mathrm{P}$ is based on the fragment method developed by Leo. $^{16}$

As shown in Table 1, there is a remarkable improvement in the lipophilicity of the synthesized derivatives, 2a-g, in comparison with the parent drug INH. Moreover, there is a quite strong linear relationship $(\mathrm{r}=0.855, \mathrm{n}=$ 7) between the values of Clog $P$ and those of the $R_{f}$ measured for these compounds. Thus, these new compounds may possess the ability for penetration of various biomembrane, ${ }^{18}$ consequently, improving their permeation toward mycobacterial cell membrane. ${ }^{19}$ Thus, improvement of lipophilic character of the new derivatives probably enhances their bioavailability to the site of action and in turn, participates in a part, in overcoming the resistance developed from poor cellular permeability. ${ }^{19}$

\section{Antitubercular activity}

The antitubercular activity of the tested compounds was carried out using Rist and Grosset proportion method according to the protocol described in the experimental part. ${ }^{17}$ The minimal inhibitory concentrations are indicated in Table 4. The antitubercular activity of the new derivatives as well as for INH was observed over a period of 8 weeks. The growth of the microorganism begins to appear in the control tube (no test compounds or INH) after six weeks. On the other hand, the tubes that has the test compounds (2a-g) or INH showed no growth of the microorganism till a period of 8 weeks. Fig. 1 shows the inhibitory activity of compound 1 and INH in comparison to the control. However, regarding the molar percentage of INH in these molecules (2a-g); they can be considered as active new entities. 
Table 4: The molar concentrations of compounds (2a-g) and INH for antitubercular activity

\begin{tabular}{|c|c|c|}
\hline $\begin{array}{c}\text { Compd. } \\
\text { No. }\end{array}$ & $\mathrm{NR}_{2}$ & $\begin{array}{c}\mathrm{MIC} \\
(\mu \mathrm{g} / \mathrm{ml})\end{array}$ \\
\hline $\mathbf{2 a}$ & $\mathrm{NMe}_{2}$ & 3.5 \\
\hline $\mathbf{2 b}$ & $\mathrm{NEt}_{2}$ & 3.5 \\
\hline $\mathbf{2 c}$ & $\mathrm{NiPr}_{2}$ & 4.0 \\
\hline $\mathbf{2 d}$ & Piperidenyl & 4.4 \\
\hline $\mathbf{2 e}$ & Morphilino & 4.0 \\
\hline $\mathbf{2 f}$ & $\begin{array}{c}\text { N-Methyl- } \\
\text { piperazinyl }\end{array}$ & 4.0 \\
\hline $\mathbf{2 g}$ & $\begin{array}{c}\text { N-Phenyl- } \\
\text { piperazinyl }\end{array}$ & 4.5 \\
\hline INH & \multicolumn{2}{|l}{1.5} \\
\hline
\end{tabular}

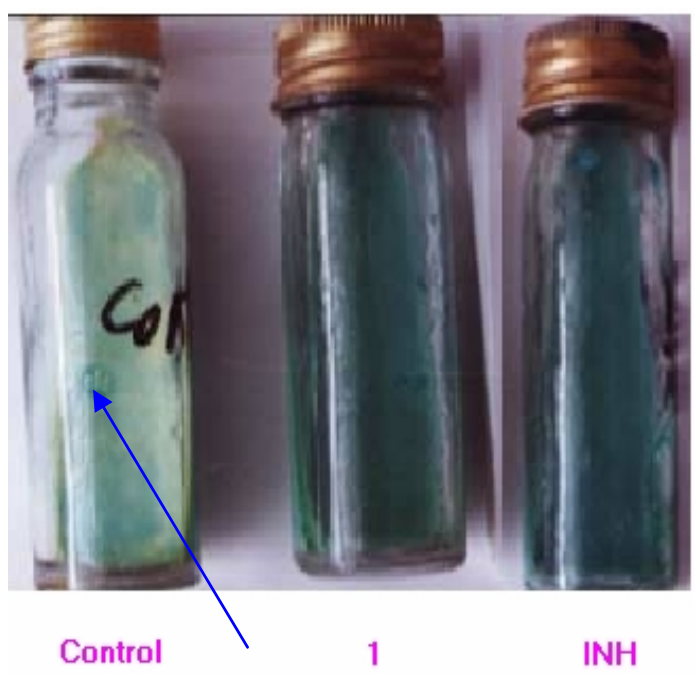

Fig. 1: Inhibitory activity of compound $\mathbf{1}$ and INH.

\section{Acknowledgement}

The authors are grateful to Dr. Mary A. Abd El-Malak, Chest Hospital, Assiut Governorate, Egypt, for providing the facilities for performing the antituberculr activity.

\section{REFERENCES}

1- R. M. Arnold, in Wilson and Gisvold's (1998) "Textbook of Organic Medicinal and Pharmaceutical Chemistry" $10^{\text {th }}$ Ed., Lippincott-Raven, New York, p. 173
2- S. Thomas, I. M. Morales, J. G. E. Solon, D. David and L. Stefan, Arch. Pharm. Pharm. Med. Chem., 11, 511 (2002).

3- B. Petrini and S. Hoffiner, International Journal of Antimicrobial Agents., 13, 293 (1999).

4- A. Pablos-Mendez, D. K. Gowda and T. R. Frieden, Bull World Health Organ., 80, 489 (2002).

5- N. P. Buu-Hoi, N. D. Xuong, N. H. Nam, F. Binon and R. J. Royer, Chem. Soc., 1358 (1953).

6- H. Tomioka, Kekkaku 77, 573 (2002).

7- C. Dye and B. G. Williams, Proc Nati Acad Sci U S A. 97: 8180 (2000).

8- C. Dye, B. G. Williams, M. A. Espinal and M. C. Raviglions, Science., 295, 2042 (2002).

9- G. Conardi, B. S. Burtun and R. T. Borchardt, In V. Pliska, B. Testa and H. Waterbeemd (Eds), (1996), "Lipophilicity in Drug Action and Toxicology", "A Series Monographs of Methods and Principles in Medicinal Chemistry", VCH. Weinheim, New York. Vol. 4, p. 233

10- R. W. Daisley and V. K. Shah, J. Pharm. Sci., 73, 407 (1984).

11- B. Piscopo, M. V. Diumo, R. Godliardi, M. Cucciniello and G. Veneruso, Bol. Soc. Ital. Biol. Sper., 63, 827 (1987).

12- E. K. Margalith and B. Winer, J. Antimicrob. Chemotherap., 2, 255 (1976).

13- P. Selvam, M. Chandramohan, E. De Clercq, M. Witvruw and C. Pannecouque, Europian J. Pharm. Sci., 14, 313 (2001).

14- R. K. Brown, R. E. Snider and M. D. Stevenson, J. Org. Chem., 21, 261 (1956).

15- T. Aboul-Fadl, F. Abdel-Hamid and E. A. Hassan, Arch. Pharm. Res., 26, 778 (2003).

16- A. J. Leo, Chem. Rev. 93, 1281 (1993).

17- G. Canetti, N. Rist, and J. Grosset, Rev. Tuber., 58, 111 (1983).

18- J. Mфss and H. Bundgaard, Int. J. Pharm., 66, 39 (1990).

19- J. K. Seydel, K. J. Schaper, Pharmazie in unserer Zeit., 24, 313 (1995). 